\title{
ANALISIS KONTRASTIF MORFOLOGI BAHASA MANDAILING TERHADAP BAHASA INDONESIA (STUDI KASUS DI DESA TANJUNG MOMPANG) KEC.PANYABUNGAN UTARA KAB.MANDAILING NATAL
}

\author{
${ }^{1}$ Dra. Nur Afifah, M.Pd, ${ }^{2}$ Nikmah Sari Hasibuan, M.Pd \\ Email: nur.afifah@um-tapsel.ac.id \& nikmah.sari@um-tapsel.ac.id \\ $1 \& 2$ Dosen Pendidikan Bahasa dan Sastra Indonesia Fakultas Keguruan dan Ilmu Pendidikan \\ Universitas Muhammadiyah Tapanuli Selatan
}

\begin{abstract}
Abstrak
Penelitian ini bertujuan untuk mendeskripsikan analisis kontrastif morfologi bahasa Mandailing terhadap bahasa Indonesia (studi kasus di desa Tanjung Mompang) Kec. Panyabungan Utara. Metode yang digunakan dalam penelitian ini adalah metode deskriptif yaitu metode yang berusaha menggambarkan suatu fenomena atau gejala yang terjadi di dalam keadaan nyata. Data Penelitian ini adalah kata-kata dalam kalimat yang mengandung kontrastif morfologi bahasa Mandailing bersumber dari masyarakat yang berjumlah 20 (dua puluh orang). Teknik pengumpulan data dengan mengutamakan observasi partisipasi yaitu reduction data, data display, dan conclusion drawing/verification. Analisis kontrastif pada morfologi kata dasar, afiksasi dan reduplikasi lebih dominan menggunakan vokal "o" di Desa Tanjung Mompang. Masyarakat di desa Tanjung Mompang tetap menguasai bahasa Mandailing dan bahasa Indonesia.
\end{abstract}

Kata Kunci: analisis kontrastif, bahasa, morfologi.

\section{PENDAHULUAN}

Bahasa merupakan alat komunikasi sehari-hari. Bahasa yang dipergunakan sebagai alat komunikasi dalam prosesnya dihasilkan melalui ujaran secara lisan, dan selanjutnya diwujudkan oleh simbol atau lambang bunyi dalam bentuk bahasa tulisan. Perkembangan bahasa dalam suatu peradaban mempunyai kaitan dengan fungsinya sebagai alat komunikasi. Semakin sering bahasa itu digunakan dalam komunikasi, maka semakin cepat bahasa itu berkembang. Tidak menutup kemungkinan suatu bahasa hilang karena ditinggalkan penuturnya.

Masyarakat Indonesia pada umumnya tergolong masyarakat dwibahasa. Mereka menguasai bahasa pertama (B1) bahasa daerah dan bahasa kedua (B2) bahasa Indonesia. Meskipun demikian, proses penguasaan kedua bahasa tersebut bervariasi sesuai dengan perkembangan pembangunan masyarakat Indonesia. Apabila dua bahasa atau lebih digunakan secara bergantian oleh penutur yang 
sama, maka dapat dikatakan bahwa bahasa-bahasa tersebut dalam keadaan saling kontak (Suwito, 1983: 39).

Kontak bahasa dapat menimbulkan hal-hal yang menguntungkan bahasa masing-masing, yaitu penyerapan atau peminjaman yang memperkaya unsurunsurnya. Akan tetapi, kontak bahasa dapat pula mengakibatkan hal-hal yang merugikan bahasa masing-masing. Kerugian ini merupakan penyimpangan dari aturan-aturan gramatika bahasa yang umum sehingga akan berakibat negatif kepada usaha menetapkan corak suatu bahasa baku atau bahasa standar dalam rangka pembinaan bahasa (Junus, 1997: 2).

Ahli-ahli linguistik sepakat bahwa orang-orang yang terlibat dalam penggunaan dua bahasa atau lebih mempunyai kecenderungan memindahkan unsur-unsur bahasa yang satu ke bahasa yang lain. Hal ini terjadi, baik pada bahasa pertama ke bahasa kedua, maupun sebaliknya (Parawansa, 1981: 5).

Terkait dengan masalah tersebut, Pranowo (1996:4) mengatakan bahwa hambatan terbesar dalam proses menguasai bahasa kedua (B2) adalah tercampurnya sistem bahasa pertama (B1) dengan sistem bahasa kedua (B2). Dalam pembelajaran bahasa kedua (bahasa Indonesia) di sekolah, siswa diharapkan dapat menguasai pola-pola serta kaidah-kaidah bahasa Indonesia dengan benar, namun pada kenyataannya tidak selalu demikian. Bahasa Indonesia siswa sering diwarnai oleh penyimpangan-penyimpangan yang disebabkan oleh dua faktor, yaitu (1) penutur bahasa pertama dalam hal ini siswa, terutama yang berdomisili di daerah lebih banyak menggunakan bahasa daerah daripada bahasa Indonesia dalam kegiatan komunikasinya sehingga kemungkinan besar penggunaan bahasa Indonesia siswa akan diwarnai oleh bahasa daerah, (2) siswa mengalami kesulitan dalam mempelajari bahasa Indonesia karena terdapat aturanaturan bahasa Indonesia yang berbeda dengan bahasa daerahnya.

Bahkan masyarakat yang berada di daerah terpencil akan lebih sering menggunakan bahasa pertama baik dalam keadaan resmi atau tidak resmi sehingga mereka mulai lupa dan tanpa sadar telah merusak bahasa itu sendiri. Perbedaan-perbedaan antara bahasa Indonesia dan bahasa daerah dapat diketahui 
dengan cara membandingkan kedua bahasa tersebut menggunakan analisis kontrastif.

Begitu juga dengan masyarakat yang berada di Desa Tanjung Mompang, kecamatan Panyabungan Utara, kabupaten Mandailing Natal yang berada di tengahtengah daerah Mandailing Natal dan terletak di daerah terpencil. Masyarakat Desa Tanjung Mompang menggunakan bahasa pertama bahasa daerah namun bahasa yang mereka gunakan berbeda dengan bahasa Mandailing pada umumnya, dan karena itu juga peneliti tertarik meneliti bahasa di daerah tersebut.

Bahasa daerah yang digunakan oleh masyarakat Tanjung Mompang sebagai alat komunikasi dalam pergaulan, baik antara keluarga, sahabat, maupun untuk kepentingan-kepentingan lain yang tidak formal dan formal mengakibatkan kesalahan dalam berbahasa. Situasi pemakaian bahasa di daerah Tanjung Mompang dalam kontaknya dengan BI dapat memengaruhi penguasaan dan penghambat proses pembelajaran B2, sehingga menimbulkan kontak bahasa dalam menggunakan bahasa Indonesia yang sering dilihat dalam kajian kontrastif bahasa.

Bahasa yang dipergunakan di desa Tanjung Mompang juga berbeda dengan bahasa Mandailing pada umumnya dan karena itu juga peneliti tertarik untuk melakukan penelitian bahasa di daerah tersebut. Berikut ini dilakukan penelitian analisis kontrastif bahasa Tanjung Mompang terhadap bahasa Indonesia (Studi kasusdi desa Tanjung Mompang) Panyabungan Utara, Mandailing Natal. Penelitian ini difokuskan untuk mengetahui perbedaan pola morfem kata dasar, kata reduplikasi dan pengulangan dalam bahasa yang dipergunakan di desa Tanjung Mompang dengan bahasa Indonesia. Sehubungan dengan apa yang telah dipaparkan maka dalam penelitian ini ynag menjadi permasalahan yang akan diteliti penulis yaitu "Bagaimanakah kontrastif morfologi kata dasar, afiksasi dan reduplikasi bahasa Mandailing terhadap bahasa Indonesia (studi kasus di desa Tanjung Mompang) Kec.Panyabungan Utara Kab.Mandailing Natal?” 


\section{TINJAUAN PUSTAKA}

A. Kajian Teori

\section{Analisis Kontrastif}

Secara umum memahami pengertian analisis kontrastif dapat ditelusuri melalui makna kedua kata tersebut. Analisis diartikan sebagai semacam pembahasan atau uraian. Yang dimaksud dengan pembahasan adalah proses atau cara membahas yang bertujuan untuk mengetahui sesuatu dan memungkinkan dapat menemukan inti permasalahannya. Permasalahan yang ditemukan itu kemudian dikupas, dikritik, diulas, dan akhirnya disimpulkan untuk dipahami (Moelino, 2003:32) menjelaskan bahwa analisis adalah penguraian suatu pokok atas berbagai bagiannya dan penelaahan bagian itu sendiri serta hubungan antarbagian untuk memperoleh pengertian yang tepat dan pemahaman arti keseluruhan. Sedangkan kontrastif diartikan sebagai perbedaan atau pertentangan antara dua hal. Perbedaan inilah yang menarik untuk dibicarakan, diteliti, dan dipahami. Moeliono menjelaskan bahwa kontrastif diartikan sebagai bersifat membandingkan perbedaan.

Secara khusus analisis kesalahan konstrantif atau lebih populer disingkat anakon adalah kegiatan memperbandingkan struktur bahasa ibu atau bahasa pertama (BI) dengan bahasa yang diperoleh atau dipelajari sesudah bahasa ibu yang lebih dikenal bahasa kedua (B2) untuk mengidentifikasi perbedaan kedua bahasa tersebut.

\section{Sekilas tentang Bahasa Mandailing}

Kabupaten daerah tingkat II Mandailing Natal, merupakan kabupaten paling selatan dari propinsi daerah tingkat I Sumatera Utara yang dibentuk berdasarkan Undang-undang RI no 12 tahun 1998 dan disyahkan pada tanggal 23 November 1998. Kabupaten ini adalah hasil pemekaran dari wilayah Kabupaten Daerah Tingkat II Tapanuli Selatan. Mandailing memiliki potensi wilayah yang beranekaragam, dengan sumber daya yang cukup luas dan subur untuk dikembangkan menjadi areal pertanian seperti kelapa, kelapa sawit, karet, padi, kulit manis, buah jeruk serta pertambakan ikan. 
Potensi lain adalah adanya deposit mineral, seperti emas, batubara, timah, belerang, besi, tembaga, seng, erak, timbal, kaolin dan marmar (http.www.Mandailing:Sejarah.AdatdanArsitekturPendahuluan.com). Harahap (2004:150) keberadaan Mandailing sudah diperhitungkan sejak abad ke-14 dengan dicantumkannya nama Mandailing dalam sumpah Palapa gajah mada pada syair ke-13 Kakawin Negarakertagama hasil karya Prapanca sebagai daerah ekspansi Majapahit sekitar tahun 1287 ke beberapa wilayah di luar Jawa. Mandailing pada masa tersebut diperkirakan sudah berkembang, dengan kondisi masyarakat yang homogen, tumbuh dan terhimpun dalam suatu ketatanegaraan kerajaan dengan kebudayaannya yang sudah tinggi di zaman tesebut. Berabad sebelum Prapanca, di Mandailing telah tumbuh masyarakat berbudaya tinggi (berdasarkan catatan sejarah serangan Rajendra Cola dari India pada tahun 1023 M ke Kerajaan Panai) di hulu sungai Barumun atau di sepanjang aliran sungai Batang Pane mulai dari Binanga, Portibi di Gunung Tua hingga lembah pegunungan Sibualbuali di Sipirok. Hal ini ditandai dengan adanya masyarakat bermarga pane di Sipirok, Angkola dan Mandailing.

Suatu masyarakat yang hidup di daerah hijau, seperti masyarakat Mandailing, memiliki kosa kata lebih banyak dalam penggunaan bahasa seharihari. Beberapa keistimewaan bahasa yang dipakai suatu masyarakat tertentu membatasi cara-cara berpikir dan pandangan masyarakat yang bersangkutan terhadap fenomena tempat mereka hidup. Harahap (2004:152) langgam bicara orang mandailing disebut pantis, irama dan intonasinya disebut landung. Susunan bahasa dan keistimewaan lain yang dimiliknya merupakan faktor dasar bagaimana suatu masyarakat memandang hakikat alam dan tempat mereka berada.

\section{Bahasa di daerah Tajung Mompang}

Masyarakat yang berada di desa Tanjung Mompang merupakan penduduk asli dari kabupaten Mandailing Natal. Daerah desa Tanjung Momang berada di tengah-tengah kabupaten Mandailing Natal. Namun, mereka menggunakan bahasa yang sangat unik, dikatakan unik karena bahasa mereka berbeda dengan 
bahasa Mandailing pada umumnya. Bahasa yang digunakan di desa Tanjung Mompang hampir sama dengan bahasa yang digunakan di daerah Marsipongi.

Namun, masyarakat yang ada di desa Tanjung Mompang paham juga dengan bahasa yang digunakan di Mandailing Natal. Masyarakat di desa Tanjung Mompang juga bisa menggunakan bahasa Indonesia. Karena itu peneliti tertarik ingin meneliti perbedaan bahasa yang digunakan di Tanjung Mompang dengan bahasa Indonesia.

\section{Hakikat Morfologi Bahasa Indonesia}

Secara etimologi kata morfologi berasal dari kata morf yang berarti bentuk dan kata logi yang berarti ilmu. Jadi, secara harfiah kata morfologi berarti ilmu mengenai bentuk. Kajian linguistik, morfologi berarti cabang ilmu bahasa yang seluk beluk bentuk kata dan perubahannya serta dampak dari perubahan itu terhadap arti (makna) dan kelas kata.

Tataran morfologi linguistik, morfologi merupakan ilmu yang mempelajari tentang jenis-jenis dan permbentukan kata dalam tataran morfologi unsur kata merupakan satuan terbesar, sedangkan satuan terkecil adalah morfem. Komunikasi yang dilakukan di masyarakat penggunaan istilah kata sering kita gunakan dalam segala kesempatan atau segala keperluan. Chaer dan Leonie (2004:1) morfologi adalah cabang tata bahasa yang menelaah struktur atau bentuk kata, utamanya melalui penggunaan morfem. Verhaar (dalam Chaer dan Leonie, 2010:32) berpendapat bahwa morfologi adalah bidang linguistik yang mempelajari susunan bagian kata secara gramatikal. Begitu pula Kridalaksana (1984:129), yang mengemukakan bahwa morfologi, yaitu (1) bidang linguistik yang mempelajari morfem dan kombinasi-kombinasinya; (2) bagian dari struktur bahasa yang mencakup kata dan bagian-bagian kata, yaitu morfem.

Definisi-definisi yang sudah diuraikan tersebut, maka morfologi adalah bagian dari ilmu bahasa yang membicarakan atau yang mempelajari seluk beluk bentuk kata serta pengaruh perubahan bentuk terhadap golongan dan arti kata, atau dengan kata lain dapat dikatakan bahwa morfologi mempelajari seluk beluk 
bentuk kata serta fungsi perubahan-perubahan bentuk kata itu, baik fungsi gramatik maupun fungsi sintaktik.

Ruang lingkup kajian morfologi adalah kata dan morfem, yaitu morfem menjadi satuan kajian terkecil dan kata menjadi satuan kajian terbesar. Finoza (2009:79) morfem adalah bentuk gramatikal terkecil yang tidak dapat dipecah lagi menjadi bentuk gramatika yang lebih kecil. Finoza (2009:80) kata adalah satuan bentuk terkecil (dari kalimat) yang dapat berdiri sendiri dan mempunyai makna sementara menurut tata bahasawan struktural, kata merupakan satuan yang disebut morfem. Mereka tidak membicarakan kata sebagai satuan bahasa, tetapi sudah merupakan satuan bebas terkecil (a minimal free form). Alwi, dkk (2003:28) kata dalam bahasa Indonesia dapat dibentuk dari kata lain, ada beberapa pengertian dan istilah yang diperlukan untuk menerangkan proses pembentukan itu. Bahasa ada bentuk (seperti kata) yang dapat dipotong-potong menjadi bagian yang lebih kecil, yang kemudian dapat dipotong lagi menjadi bagian yang lebih kecil lagi sampai kebentuk yang jika dipotong lagi, tidak mempunyai makna.

\subsection{Kata Dasar atau Leksem}

Kamus besar bahasa Indonesia tahun 2008, leksem merupakan satuan leksikal dasar yang abstrak yang mendasari berbagai bentuk kata. Bentuk kata yang dimaksud dalam pembahasan ini adalah kata dasar. Kata dalam morfologi merupakan satuan terbesar, dibentuk melalui salah satu proses morfologi (afiksasi, reduplikasi, komposisi, akronimisasi dan konversi).

Kata dasar adalah kata yang belum diberi imbuhan. Kata dasar merupakan kata yang menjadi dasar awal pembentukan kata yang lebih besar. Contohnya adalah makan, duduk, pulang, tinggal, datang, minum, langkah, pindah dan lainlain. Kata dasar adalah unsur bahasa yang diucapkan atau dituliskan yang merupakan perwujudan kesatuan perasaan dan pikiran yang dapat digunakan dalam berbahasa. Contoh: makan, lari, pergi, datang, mandi dan lain sebagainya. 


\subsection{Kata Turunan atau Afiksasi}

Kata turunan atau disebut dengan kata berimbuhan adalah kata-kata yang telah berupa bentuk dan makna. Perubahan ini dikarenakan kata-kata tersebut telah diberi imbuhan yang berupa awalan (afiks), akhiran (sufiks), sisipan (infiks), dan awalan-akhiran (konfiks). Afiksasi merupakan nama lain dari morfem terikat. Morfem terikat merupakan kata yang tidak dapat berdiri sendiri. Kata yang dapat berdiri sendiri disebut morfem bebas. Morfem bebas merupakan kata dasar yang dapat berdiri sendiri. Kata dasar dapat berupa kata benda, kata kerja, kata sifat, dan lain-lain.

\subsection{Pengulangan atau Reduplikasi}

Melihat konsep di atas, dalam konteks ilmu bahasa, reduplikasi termasuk dalam kajian morfologi karena reduplikasi memiliki status yang sama dengan proses pembentukan kata dalam morfologi, sebagaimana afiksasi dan penjamakan kata (kompositam).

Ramlan (2001:64) kata ulang atau reduplikasi adalah proses pengulangan satuan gramatik, baik seluruhnya atau sebagian, baik dengan variasi fonem maupun tidak. Hasil pengulangan itu disebut kata ulang, sedangkan satuan yang diulang merupakan bentuk dasarnya. Reduplikasi atau bentuk pengulangan dalam bahasa Indonesia yang terjadi pada tataran fonologis, morfologis, maupun tataran sintaksis. Muslich (dalam Kosasih, 2011:134), berpendapat bahwa proses pengulangan merupakan peristiwa pembentukan kata dengan jalan mengulang bentuk dasar, baik bervariasi fonem maupun tidak, baik berkombinasi dengan afiks maupun tidak. Kridalaksana (1984:143) menjelaskan bahwa reduplikasi adalah suatu proses dan hasil pengulangannya satuan bahasa sebagai alat fonologis dan gramatikal. Konsep di atas, dalam konteks ilmu bahasa, reduplikasi termasuk dalam kajian morfologi karena reduplikasi memiliki status yang sama dengan proses pembentukan kata dalam morfologis, sebagaimana afiksasi dan penjamakan kata (kompositam).

Definisi-defenisi pengulangan kata menurut beberapa ahli di atas maka dapat disimpulkan bahwa reduplikasi adalah proses pengulangan kata, baik 
secara utuh maupun secara sebagian, baik bervariasi fonem maupun tidak, baik berkombinasi dengan afiks maupun tidak dan menjadi satuan bahasa sebagai alat fonologis dan gramatikal serta merupakan kajian dari morfologi. Chaer dan Agustina (2010:286) hasil pengulangan itu dapat dibedakan adanya empat macam kata ulang, yaitu (1) kata ulang utuh atau murni, (2) kata ulang berubah bunyi, (3) kata ulang sebagian, dan (4) kata ulang berimbuhan.

\section{B. Kerangka Berfikir}

Secara khusus analisis kesalahan konstrantif atau lebih populer disingkat anakon adalah kegiatan memperbandingkan struktur bahasa ibu atau bahasa pertama (BI) dengan bahasa yang diperoleh atau dipelajari sesudah bahasa ibu yang lebih dikenal bahasa kedua (B2) untuk mengidentifikasi perbedaan kedua bahasa tersebut. Di desa Tanjung Mompang mereka sering mencampuradukkan bahasa yang mereka gunakan dengan bahasa Indonesia. Bahasa yang digunakan di desa Tanjung Mompang berbeda dengan bahasa Mandailing pada umumnya, walau letak desa Tanjug Momang ditengah-tengah kabupaten Mandailing Natal namun bahasa mereka hampir mirip dengan bahasa Muarasipongi. Dalam kehidupan bermasyarakat sering terjadi pencampuradukan bahasa, begitu juga dengan masyarakat yang ada di desa Tanjung Mompang, dank arena itulah peneliti tertarik ingin meneliti perbedaan atau yang disebut analisis kontrastif pada bahasa Mandailing terhadap bahasa Indonesia yang studi kasusnya berada di desa Tanjung Mompang. Peneliti akan mengkaji atau menganalisis lebih dalam tentang analisis kontrastif morfologi bidang kata dasar, afiksasi dan reduplikasi.

\section{METODOLOGI PENELITIAN}

Jenis penelitian ini adalah penelitian kualitatif. Sebagaimana yang dikemukakan Bogdan dan Taylor dalam Moleong (2002:60), mendefinisikan penelitian kualitatif merupakan penelitian yang menghasilkan data deskriptif berupa kata-kata tertulis atau tulisan dari orang-orang dan perilaku yang dapat diamati. Metode yang digunakan dalam penelitian ini adalah metode deskriptif yaitu metode yang berusaha menggambarkan suatu fenomena atau gejala yang terjadi di dalam keadaan nyata. Hal ini sesuai dengan Ali (1987:120), "Metode 
deskriptif digunakan untuk memecahkan masalah dan menjawab permasalahan yang dicapai pada situasi sekarang yang dilakukan dengan menempuh langkahlangkah pengumpulan, klasifikasi dan analisis atau pengumpulan data, membuat kesimpulan dan laporan dengan tujuan membuat penggambaran deskriptif situasi".

Penelitian ini dilaksanakan di desa Tanjung Mompang, kecamatan Panyabungan Utara, kabupaten Mandaiing natal. Waktu yang dipergunakan sampai selesai dalam pengolahan penelitian sehingga bisa ditarik kesimpulan.

Data Penelitian ini adalah kata-kata dalam kalimat yang mengandung kontrastif morfologi bahasa Mandailing. Data penelitian ini bersumber dari masyarakat yang berjumlah 20 (dua puluh orang) orang yang berdasarkan segmen masyarakat yaitu berdasarkan 4 (empat) kategori yaitu pendidikan, pekerjaan, usia dan jenis kelamin. Para informan yang dipilih adalah penutur yang dipilih berdasarkan:

1. Berjenis kelamin pria atau wanita

2. Berusia antara 25-26 tahun (tidak pikun)

3. Sehat jasmani dan rohani

Setelah melalukan wawancara yang sekaligus di rekam dalam tape recorder maka data tersebut akan diolah sesuai dengan morfologi kata dasar, afiksasi dan reduplikasi.

Penelitian ini penulis melakukan teknik pengumpulan datanya dengan mengutamakan observasi partisipasi yang berarti bahwa penulis mengadakan kontak langsung dengan para informan yang terlibat dalam suatu wawancara ataupun percakapan dan merekam langsung bahasa lisan dari para informan tersebut dengan tape recorder. Data yang dikumpul kemudian dikelompokkan

Teknik analisis data pada penelitian ini merujuk pada teori Miles dan Huberman (dalam Sugiyono, 2013:337) yang mengemukakan bahwa aktivitas dalam analisis data kualitatif dilakukan secara interaktif dan berlangsung secara terus menerus sampai tuntas. Aktivitas dalam analisis data, yaitu reduction data, data display, dan conclusion drawing/verification. 
(1) Data Reduction (Reduksi Data)

Data yang telah direduksi akan memberikan gambaran yang jelas dan mempermudah peneliti untuk melakukan pengumpulan data selanjutnya, dan mencarinya bila diperlukan Miles dan Huberman mengungkapkan bahwa mereduksi data berarti merangkum, memilih hal-hal pokok, memfokuskan pada hal-hal penting, dicari tema dan polanya dan membuang yang tidak perlu.

\section{(2) Data Display (Penyajian Data)}

Penyajian data dalam penelitian kualitatif bisa dilakukan dalam bentuk uraian singkat, bagan hubungan antarkategori, flowchart, dan sejenisnya. Miles dan Huberman menyampaikan bahwa yang paling sering digunakan untuk menyajikan data untuk penelitian kualitatif adalah dengan teks yang bersifat naratif.

\section{(3) Conclusion Drawing/Verifikasi}

Langkah ketiga dalam analisis data kualitatif adalah penarikan kesimpulan dan verifikasi. Kesimpulan dalam penelitian kualitatif diharapkan berupa temuan baru yang sebelumnya belum pernah ada. Temuan dapat berupa deskriptif atau gambaran suatu objek yang sebelumnya masih remang-remang atau g€ . sehingga setelah diteliti menjadi jelas, dapat berupa kausal atau interaktif, hipotesis atau teori.

\section{HASIL DAN PEMBAHASAN}

\section{Hasil dan Pembahasan}

\section{Analisis kontrastif bahasa di Tanjung Mompang dan bahasa Indonesia}

Melalui wawancara terhadap masyarakat analaisis kontrastif yang ditemukan berbentuk kata dasar, afiksasi, reduplikasi yang sering mereka pakai dalam kehidupan sehari-hari. 
Tabel l. Data analisis kontarastif kata dasar di desa Tanjung Mompang dan bahasa Indonesia

\begin{tabular}{|c|c|c|c|}
\hline No. & $\begin{array}{c}\text { Bahasa di Desa } \\
\text { Tanjung } \\
\text { Mompang } \\
\end{array}$ & $\begin{array}{c}\text { Bahasa } \\
\text { Mandailing }\end{array}$ & Bahasa Indonesia \\
\hline 1. & $A i^{\prime}$ & Aek & Air \\
\hline 2. & Sorewa & Salaor & Celana \\
\hline 3. & Bo moru & Marmara & Celaka \\
\hline 4. & Dogu & Isang & Dagu \\
\hline 5. & $I k u$ & Ikur & Ekor \\
\hline 6. & Koloparet & Male & Lapar \\
\hline 7. & Jerih & Loja & Lelah \\
\hline 8. & Moti & Mate & Mati \\
\hline 9. & Maket & Mangan & Makan \\
\hline 10 & Pulak & Mulak & Pulang \\
\hline 11 & Molangkah & Kehe & Pergi \\
\hline 12 & Perepetak & Potang & Petang \\
\hline 13 & Tidu’ & Modom & Tidur \\
\hline 14 & $K u b u^{\prime}$ & Tanom & Kubur \\
\hline 15 & Pagak & Tiop & Pegang \\
\hline 10 & Cinto & Cinta & Cinta \\
\hline 17 & Sirop & Siram & Siram \\
\hline 18 & Tukak & Tukang & Tukang \\
\hline 19 & Lori & Lojong & Lari \\
\hline 20 & Jalet & Dalan & Jalan \\
\hline
\end{tabular}

Tabel ll. Data analisis kontarastif afiksasi di desa Tanjung Mompang dan bahasa Indonesia

\begin{tabular}{|r|l|l|l|}
\hline No. & $\begin{array}{l}\text { Bahasa di Desa } \\
\text { Tanjung Mompang }\end{array}$ & $\begin{array}{l}\text { Bahasa } \\
\text { Mandailing }\end{array}$ & $\begin{array}{l}\text { Bahasa } \\
\text { Indonesia }\end{array}$ \\
\hline 1. & Bomoin & Marmayam & Bermain \\
\hline 2. & Mengambi & Mambuot & Mengambil \\
\hline 3. & Mononti & Painteon & Menunggu \\
\hline 4. & Mongorejo ke & Mangkarejoon & Mengerjakan \\
\hline 5. & Dimaket & Ipangan & Dimakan \\
\hline 6. & Diminum & iminum & Diminum \\
\hline 7. & Ditelet & Itolon & Ditelan \\
\hline 8. & Do sikola & I sikola & Di sekolah \\
\hline 9. & Do ruangin & I ruangan & Di ruangan \\
\hline 10 & Do rumah & I bagas & Di rumah \\
\hline
\end{tabular}




\begin{tabular}{|r|l|l|l|}
\hline 11 & Bokorejo & Karejo & Bekerja \\
\hline 12 & Borendop & Marrondam & Berendam \\
\hline 13 & Motornyo & Motorna & Mobilnya \\
\hline 14 & Jodinyo & Jadina & Akhirnya \\
\hline 15 & Momakei & Mamake & Memakai \\
\hline 16 & Botunyo & Batuna & Batunya \\
\hline 17 & Monoruske & Manaruskon & Melanjutkan \\
\hline 18 & Monyuruh & Manyuruh & Menyeruh \\
\hline 19 & Molanjutke & Malanjutkon & Meneruskan \\
\hline 20 & Porkampungen & Parkampungan & Perkampungan \\
\hline
\end{tabular}

Tabel Ill. Data analisis kontarastif reduplikasi di desa Tanjung Mompang dan bahasa Indonesia

\begin{tabular}{|c|c|c|c|}
\hline No. & $\begin{array}{c}\text { Bahasa di Desa } \\
\text { Tanjung } \\
\text { Mompang }\end{array}$ & $\begin{array}{c}\text { Bahasa } \\
\text { Mandailing }\end{array}$ & Bahasa Indonesia \\
\hline 1. & Bolori-lori & $\begin{array}{l}\text { Marlojong- } \\
\text { lojong }\end{array}$ & Berlari-lari \\
\hline 2. & Maket-maket & $\begin{array}{l}\text { Marmangan- } \\
\text { mangan }\end{array}$ & Makan-makan \\
\hline 3. & Komori-komori & Tuson-tuson & Kemari-kemari \\
\hline 4. & Bologu-logu & $\begin{array}{l}\text { Marlogu- } \\
\log u\end{array}$ & Bernyanyi-nyanyi \\
\hline 5. & Monori-nori & Manari-nari & Menari-nari \\
\hline 6. & So baik-baiknyo & $\begin{array}{l}\text { Sadenggan- } \\
\text { dengganna }\end{array}$ & Sebaik - baiknya \\
\hline 7. & $\begin{array}{l}\text { So banyak- } \\
\text { banyaknyo }\end{array}$ & $\begin{array}{l}\text { Sabahat- } \\
\text { bahatna }\end{array}$ & $\begin{array}{l}\text { Sebanyak } \\
\text { banyaknya }\end{array}$ \\
\hline 8. & $\begin{array}{l}\text { So pintar- } \\
\text { pintarnyo }\end{array}$ & $\begin{array}{l}\text { Sapintar- } \\
\text { pintarna }\end{array}$ & $\begin{array}{l}\text { Sepintar } \\
\text { pintarnya }\end{array}$ \\
\hline 9. & $\begin{array}{l}\text { Sobagak- } \\
\text { bagaknyo }\end{array}$ & $\begin{array}{l}\text { Sadeges- } \\
\text { degesna }\end{array}$ & $\begin{array}{l}\text { Secantik } \\
\text { cantiknya }\end{array}$ \\
\hline 10 & $\begin{array}{l}\text { Sopandei- } \\
\text { pandeinyo }\end{array}$ & $\begin{array}{l}\text { Samalo- } \\
\text { malona }\end{array}$ & $\begin{array}{l}\text { Sepandai } \\
\text { Pandainya }\end{array}$ \\
\hline 11 & So uju-ијunyo & $\begin{array}{l}\text { Sabodo- } \\
\text { bodoma }\end{array}$ & $\begin{array}{l}\text { Sebodoh } \\
\text { bodohnya }\end{array}$ \\
\hline 12 & $\begin{array}{l}\text { Soburuk- } \\
\text { buruknyo }\end{array}$ & Sajat-jatna & Sejelek - jeleknya \\
\hline 13 & $\begin{array}{l}\text { Sokereh- } \\
\text { kerehnyo }\end{array}$ & $\begin{array}{l}\text { Sakoras- } \\
\text { korasna }\end{array}$ & Sekeras - kerasnya \\
\hline 14 & Soholis-holisnyo & $\begin{array}{l}\text { Saalus- } \\
\text { alusna }\end{array}$ & Sehalus - halusnya \\
\hline
\end{tabular}




\begin{tabular}{|r|l|l|l|}
\hline 15 & Pulam-balik & Pae-paulu & Bolak-balik \\
\hline 10 & Torum-bakambik & $\begin{array}{l}\text { Tarombang- } \\
\text { ambing }\end{array}$ & $\begin{array}{l}\text { Terombang- } \\
\text { ambing }\end{array}$ \\
\hline 1 & Tidu'-tiduret & $\begin{array}{l}\text { Marmodom- } \\
\text { modom }\end{array}$ & Tidur-tiduran \\
\hline 1 & Teran-terangin & $\begin{array}{l}\text { Martorang- } \\
\text { torang }\end{array}$ & Terang-benderang \\
\hline 19 & Kebake-bake & $\begin{array}{l}\text { Hobar- } \\
\text { hobari }\end{array}$ & Kabar-kabari \\
\hline 21 & Gerak-gerik & Gerak-gerik & Gerak-gerik \\
\hline
\end{tabular}

\section{Analisis kata Dasar}

1. $A i$ ', kata dasar "ai" di dalam bahasa yang dipakai di desa Tanjung Mompang berarti kata "air" dalam bahasa Indonesia dan dalam bahasa Mandailing berarti kata "aek"

2. Sorewa, kata dasar "sorawe" dalam bahasa yang dipakai di desa Tanjung Mompang berarti kata "celana" dalam bahasa Indonesia dan dalam bahasa Mandailing berarti kata "salaor"

3. Bo moru, kata dasar "bo moru" di dalam bahasa yang dipakai di desa Tanjung Mompang berarti kata "celaka" dalam bahasa Indonesia dan dalam bahasa Mandailing berarti kata "marmara"

4. Dogu, kata dasar "dogu" di dalam bahasa yang dipakai di desa Tanjung Mompang berarti kata "dagu" dalam bahasa Indonesia dan dalam bahasa Mandailing berarti kata "isang"

5. $I k u$, kata dasar "iku" di dalam bahasa yang dipakai di desa Tanjung Mompang berarti kata "ekor" dalam bahasa Indonesia dan dalam bahasa Mandailing berarti kata "ikur"

6. Koloparet, kata dasar "koloparet" di dalam bahasa yang dipakai di desa Tanjung Mompang berarti kata "lapar" dalam bahasa Indonesia dan dalam bahasa Mandailing berarti kata "male"

7. Jerih, kata dasar "jerih" di dalam bahasa yang dipakai di desa Tanjung Mompang berarti kata "lelah" dalam bahasa Indonesia dan dalam bahasa Mandailing berarti kata "loja" 
8. Moti, kata dasar "moti" di dalam bahasa yang dipakai di desa Tanjung Mompang berarti kata "mati" dalam bahasa Indonesia dan dalam bahasa Mandailing berarti kata "mate"

9. Maket, kata dasar "maket" di dalam bahasa yang dipakai di desa Tanjung Mompang berarti kata "makan" dalam bahasa Indonesia dan dalam bahasa Mandailing berarti kata "mangan"

10. Pulak, kata dasar "pulak" di dalam bahasa yang dipakai di desa Tanjung Mompang berarti kata "pulang" dalam bahasa Indonesia dan dalam bahasa Mandailing berarti kata "mulak"

11. Molangkah, kata dasar "molangkah" di dalam bahasa yang dipakai di desa Tanjung Mompang berarti kata "langkah" dalam bahasa Indonesia dan dalam bahasa Mandailing berarti kata "malangka"

12. Perepetak, kata dasar "perepetak" di dalam bahasa yang dipakai di desa Tanjung Mompang berarti kata "petang" dalam bahasa Indonesia dan dalam bahasa Mandailing berarti kata "potang"

13. Tidu', kata dasar "tidu" di dalam bahasa yang dipakai di desa Tanjung Mompang berarti kata "tidur" dalam bahasa Indonesia dan dalam bahasa Mandailing berarti kata "modom"

14. Kubu', kata dasar "kubu'", di dalam bahasa yang dipakai di desa Tanjung Mompang berarti kata "kubur" dalam bahasa Indonesia dan dalam bahasa Mandailing berarti kata "tanom"

15. Pagak, kata dasar "pagak" di dalam bahasa yang dipakai di desa Tanjung Mompang berarti kata "pegang" dalam bahasa Indonesia dan dalam bahasa Mandailing berarti kata "tiop"

16. Cinto, kata dasar "cinto"” di dalam bahasa yang dipakai di desa Tanjung Mompang berarti kata "cinta" dalam bahasa Indonesia dan dalam bahasa Mandailing berarti kata "cinta"

17. Sirop, kata dasar "sirop" di dalam bahasa yang dipakai di desa Tanjung Mompang berarti kata "siram" dalam bahasa Indonesia dan dalam bahasa Mandailing berarti kata "siram" 
18. Tukak, kata dasar "tukak" di dalam bahasa yang dipakai di desa Tanjung Mompang berarti kata "tukang" dalam bahasa Indonesia dan dalam bahasa Mandailing berarti kata "tukang"

19. Lori, kata dasar "lori'" di dalam bahasa yang dipakai di desa Tanjung Mompang berarti kata "lari" dalam bahasa Indonesia dan dalam bahasa Mandailing berarti kata "lojong"

20. Jalet, kata dasar "jalet" di dalam bahasa yang dipakai di desa Tanjung Mompang berarti kata "jalan" dalam bahasa Indonesia dan dalam bahasa Mandailing berarti kata "dalan"

\section{Analisis afiksasi}

1. Bomoin, Ada pun analisiis kontrastif pada afiksasi terdapat seperti Kata "bomoin" di desa Tanjung Mompang dan dalam bahasa Indonesianya adalah "bermain" yang kata dasarnya adalah "main". Awalan "ber- dalam bahasa Indonesia menjadi awalan "bo-" di desa Tanjung Mompang, sedangkan awalan ber- dalam bahasa Mandailing "mar-". Jadi jelaslah bahasa yang dipakai di desa Tanjung Mompang berbeda dengan bahasa Mandailing umumnya.

2. Mengambi, Kata "mengambi" dalam bahasa yang digunakan di Tanjung Mompang mendapat kemiripin dalam bahasa Indonesia, hanya peleburan pada huruf "l”" yaitu kata "mengambil" menjadi "mengambi" namun dalam bahasa Mandailing kata mengambil adalah "mambuot".

3. Mononti, dalam bahasa Indonesia "menunggu" dan dalam bahasa Mandailing "painteon". "mononti" mempunyai awalan "mo- dalam bahasa yang digunakan di Desa Tanjung Mompang, ssedangkan dalam bahasa Indonesia menjadi awalan "me- dan dalam bahasa Mandailing menjadi awalan "pa-"

4. Mongorejoke, yang dalam bahasa Indonesia "mengerjakan" kata dasarnya adalah "kerja" dan dalam bahasa Mandailing "mangkarejoon". Dalam bahasa yang dipakai di Tanjung Mompang "mongorejoke" mempunyai afiksasi “mong-ke” sedangkan bahasa Mandailing umumnya menggunakan afiksasi 
"mang-on" dana afiksasi yang digunakan dalam bahasa Indonesia "mengkan"

5. Dimaket, dalam bahasa Indonesia "dimakan" dan bahasa Mandailingnya yaitu "ipangan". Awalan "di.." dalam bahasa yang dipakai di Desa Tanjung Mompang sama dengan yang digunakan dalam bahasa Indonesia namun yang berbeda dalam bahasa Mandailing awalan "di.." menjadi awalan "i...".

6. Diminum,sama dengan awalan yang ada dalam bahasa Indonesia, yang dipakai dalam bahasa yang di Tanjung Mompang juga menggunakan awalan “di.." perbedaanya pada bahasa Mandailing diganti menjadi awalan "i.."

7. Ditelet,kata dasar dalam bahasa Indonesia yaitu "telan" dan dalam bahasa Mandailing "tolon" sedangkan dalam bahasa yang dipakai di desa Tanjung Mompang yaitu "telet". Awalan yang dipakai antara bahasa Indonesia dengan bahasa yang dipakai di Tanjung Mompang juga sama, yang beda penggunaan awalan di Mandailing Natal yaitu awalan "di..." menjadi awalan "i..."

8. Do sikola,kata dasar dalam bahasa Indonesia adalah "sekolah" dan dalam bahasa Mandailing adalah "sikola". Penyebutan kata dasar bahasa Mandailing dengan bahasa yang dipakai di Tanjung Mompang sama. Namun, afiksasi dalam kata ini berubah yaitu awalan "do.." dalam bahasa yang dipakai di desa Tanjung Mompang menjadi awalan "di..." dalam bahasa Indonesia, sedangkan dalam bahasa Mandailing menjadi awalan "i..."

9. Do ruangin, kata dasar bahasa Indonesia dan bahasa Mandailing "ruangan" dalam bahasa yang dipakai di desa Tanjung Mompang "ruangin" dan mendapat awalan "do..." dalam bahasa yang dipakai dalam bahasa Tanjung Mompang, "I" dalam bahasa Mandailing dan "di" dalam bahasa Indonesia

10. Do rumah, awalan "do" dalam bahasa yang dipakai di desa Tanjung Mompang menjadi awalan "I" dalam bahasa Mandailing dan "di" dalam bahasa Indonesia

11. Bokorejo,kata dasar dalam bahasa Indonesia yaitu "kerja" dan dalam bahasa Mandailing "karejo" sedangkan kata dasar yang dipakai di desa Tanjung Mompang menjadi "korejo". Penambahan awalan dalam bahasa yang 
digunakan di desa Tanjung Mompang "bo...” yang dalam bahasa Mandailing "mar..." dan dalam bahasa Indonesia menjadi awalan "be...".

12. Borendop, kata dasar dalam bahasa Indonesia yaitu "rendam" dan dalam bahasa Mandailing manjadi "rondam" dan dalam bahasa yang dipakai di desa Tanjung Mompang menjadi "rendop". Awalan yang dipakai dalam bahasa yang digunakan di desa Tanjung Mompang "bo..." yang dalam bahasa Mandailing menjadi awalan "mar..." dan dalam bahasa Indoenesia menjadi awalan "be..."

13. Motornyo, kata dasar dalam bahasa Indonesia adalah "mobil" sedangkan dalam bahasa Mandailing dan bahasa yang dipakai di desa Tanjung Mompang sama yaitu "motor". Akhiran yang digunakan dalam bahasa Indonesia “...-nya” dan dalam bahasa Mandailing “...-na” sedangkan dalam bahasa yang dipakai di desa Tanjung Mompang yaitu "...-nyo"

14. Jodinyo, kata dasar dalam bahasa Indonesia dan bahasa Mandailing yaitu “akhir" dan bahasa yang dipakai di dsa Tanjung Mompang kata dasarnya menjadi “jodi”. Akhiran yang dipakai dalam bahasa Indonesia adalah “...nya” pada bahasa yang dipakai di desa Tanjung Mompang menjadi “...-nyo” dan dalam bahasa Mandailing menjadi akhiran “...-na”

15. Momakei, kata dasar dalam bahasa Indonesia adalah "pakai" dan dalam bahasa Mandailing "pake" dan kata dasar yang terdapat di desa tanjug Mompang "make" afiksasi yang terdapat dalam bahasa Indonesia yaitu "me.." dan dalam bahasa Indonesia terdapat afiksasi "ma..."sedangkan afiksasi yang dipakai di desa Tanjung Mompang yaitu "mo..."

16. Botunyo, kata dasar dalam bahasa Indonesia dan bahasa Mandailing adalah "batu" kemudian terjadi perbedaan akhiran, yang dalam bahasa Indonesia seharusnya menjadi akhiran "...-nya" dan dalam bahasa Mandailing terdapat akhiran "...-na"

17. Monoruske, kata dasar dalam bahasa Indonesia "torus" dan dalam bahasa Mandailing dan juga bahasa yang dipakai di desa Tanjung Mompang "torus". Selanjutnya terdapat perbedaan afiksasi yaitu dalam bahasa Indonesia seharusnya afiksasi yang digunakan adalah "me...kan" dalam bahasa 
Mandailing afiksasi "ma...kon" sedangkan dalam bahasa yang digunakan di desa Tanjung Mompang adalah afiksasi "mo...ke".

18. Monyuruh, kata dasar yang dipakai dalam bahasa Indonesia dan bahasa Mandailing adalah "suruh", terdapat perbedaan pada afiksasi yang dalam bahasa Indonesia adalah afiksasi "me..." dalam bahasa Mandailing mnejadi afiksasi "ma..." dan dalam bahasa yang dipakai di desa Tanjung Mompang menjadi "mo...".

19. Molanjutke, kata dasar dalam bahasa Indonesia dan dalam bahasa Mandailing adalah "lanjut" hanya perubahan pada afiksasi yang dipakai, jika afiksasi yang dipakai di desa Tanjung Mompang adalah "mo...ke" dalam bahasa Indonesia afiksasi "me...-kan" dan dalam bahasa Mandailing terdapat afiksasi "ma...kon"

20. Porkampungen, kata dasar dalam bahasa Indonesia adalah "kampung" lalu ditambah afiksasi "per...an", afiksasi tersebut dalam bahasa yang dipakai dalam bahasa Mandailing dan bahasa yang digunakan di desa Tanjung Mompang berbeda. "por...en" dalam bahasa yang dipakai di Desa Tanjung Mompang, sedangkan dalam bahasa Mandailing afiksasi menjadi "par...-an"

\section{Reduplikasi}

1. Bolori-lori, pengulangan kata yang dipakai di desa Tanjung Mompang berbeda dengan yang digunakan dalam bahasa Mandailing dan bahasa Indonesia, dalam bahasa Mandailing berarti "marlojong-lojong" dan dalam bahasa Indonesia berarti "berlari-lari”

2. Maket-maket, pengulangan kata yang dipakai di desa Tanjung Mompang berbeda dengan yang digunakan dalam bahasa Mandailing dan bahasa Indonesia, dalam bahasa Mandailing berarti "marmangan-mangan" dan dalam bahasa Indonesia berarti "makan-makan"

3. Komori-komori, pengulangan kata yang dipakai di desa Tanjung Mompang berbeda dengan yang digunakan dalam bahasa Mandailing dan bahasa 
Indonesia, dalam bahasa Mandailing berarti "tuson-tuson" dan dalam bahasa Indonesia berarti "kemari-kemari"

4. Bologu- $\log u$, pengulangan kata yang dipakai di desa Tanjung Mompang berbeda dengan yang digunakan dalam bahasa Mandailing dan bahasa Indonesia, dalam bahasa Mandailing berarti "marlogu-logu" dan dalam bahasa Indonesia berarti "bernyanyi-nyanyi"

5. Monori-nori, pengulangan kata yang dipakai di desa Tanjung Mompang berbeda dengan yang digunakan dalam bahasa Mandailing dan bahasa Indonesia, dalam bahasa Mandailing berarti "manari-nari” dan dalam bahasa Indonesia berarti "menari-nari”

6. So baik-baiknyo, pengulangan kata yang dipakai di desa Tanjung Mompang berbeda dengan yang digunakan dalam bahasa Mandailing dan bahasa Indonesia, dalam bahasa Mandailing berarti "sadengan-dengganna" dan dalam bahasa Indonesia berarti "sebaik-baiknya"

7. So banyak-banyaknyo, pengulangan kata yang dipakai di desa Tanjung Mompang berbeda dengan yang digunakan dalam bahasa Mandailing dan bahasa Indonesia, dalam bahasa Mandailing berarti "sabahat-bahatna" dan dalam bahasa Indonesia berarti "sebanyak-banyaknya"

8. So pintar-pintarnyo, pengulangan kata yang dipakai di desa Tanjung Mompang berbeda dengan yang digunakan dalam bahasa Mandailing dan bahasa Indonesia, dalam bahasa Mandailing berarti "sapintar-pintarna" dan dalam bahasa Indonesia berarti "sepintar-[intarnya"

9. Sobagak-bagaknyo, pengulangan kata yang dipakai di desa Tanjung Mompang berbeda dengan yang digunakan dalam bahasa Mandailing dan bahasa Indonesia, dalam bahasa Mandailing berarti "sadeges-degesna" dan dalam bahasa Indonesia berarti "secantik-cantiknya"

10. Sopandei-pandeinyo, pengulangan kata yang dipakai di desa Tanjung Mompang berbeda dengan yang digunakan dalam bahasa Mandailing dan bahasa Indonesia, dalam bahasa Mandailing berarti "samalo-malona" dan dalam bahasa Indonesia berarti "sepandai-pandainya" 
11. So uju-ujunyo, pengulangan kata yang dipakai di desa Tanjung Mompang berbeda dengan yang digunakan dalam bahasa Mandailing dan bahasa Indonesia, dalam bahasa Mandailing berarti "saoto-otona" dan dalam bahasa Indonesia berarti "sebodoh-bodohnya"

12. Soburuk-buruknyo, pengulangan kata yang dipakai di desa Tanjung Mompang berbeda dengan yang digunakan dalam bahasa Mandailing dan bahasa Indonesia, dalam bahasa Mandailing berarti "sajat-jatna" dan dalam bahasa Indonesia berarti "seburuk-buruknya"

13. Sokereh-kerehnyo, pengulangan kata yang dipakai di desa Tanjung Mompang berbeda dengan yang digunakan dalam bahasa Mandailing dan bahasa Indonesia, dalam bahasa Mandailing berarti "sakoras-korasna" dan dalam bahasa Indonesia berarti "sekeras-kerasnya"

14. Soholis-holisnyo, pengulangan kata yang dipakai di desa Tanjung Mompang berbeda dengan yang digunakan dalam bahasa Mandailing dan bahasa Indonesia, dalam bahasa Mandailing berarti "saalus-alusna" dan dalam bahasa Indonesia berarti "sehalus-halusnya"

15. Pulam-balik, pengulangan kata yang dipakai di desa Tanjung Mompang berbeda dengan yang digunakan dalam bahasa Mandailing dan bahasa Indonesia, dalam bahasa Mandailing berarti "pae-paulu” dan dalam bahasa Indonesia berarti "bolak-balik"

16. Torum-bakambik, pengulangan kata yang dipakai di desa Tanjung Mompang berbeda dengan yang digunakan dalam bahasa Mandailing dan bahasa Indonesia, dalam bahasa Mandailing berarti "tarambang-ambing” dan dalam bahasa Indonesia berarti "terambang-ambing"

17. Tidu' -tiduret, pengulangan kata yang dipakai di desa Tanjung Mompang berbeda dengan yang digunakan dalam bahasa Mandailing dan bahasa Indonesia, dalam bahasa Mandailing berarti "marmodom-modom" dan dalam bahasa Indonesia berarti "tidur-tiduran"

18. Teran-terangin, pengulangan kata yang dipakai di desa Tanjung Mompang berbeda dengan yang digunakan dalam bahasa Mandailing dan bahasa 
Indonesia, dalam bahasa Mandailing berarti "martorang-torang" dan dalam bahasa Indonesia berarti "terang-bendrang"

19. Kebake-bake, pengulangan kata yang dipakai di desa Tanjung Mompang berbeda dengan yang digunakan dalam bahasa Mandailing dan bahasa Indonesia, dalam bahasa Mandailing berarti "hobar-hobari" dan dalam bahasa Indonesia berarti "kabar-kabari"

20. Gerak-gerik, pengulangan kata yang dipakai di desa Tanjung Mompang sama juga dengan yang digunakan dalam bahasa Indonesia dan bahasa Mandailing.

\section{B.Pembahasan}

\section{Kata Dasar}

Dari hasil analisis dan wawancara yang dilakukan, ternyata kata dasar Bahasa Mandailing dengan bahasa yang digunakan di Desa Tanjung Mompang banyak perbedaan. Analisis kontrastif yang terdapat dalam kata dasar lebih banyak dan lebih dominan memakai vokal 'o'. kata yang dimaksud seperti kata “dagu, mati, cinta, siram, lari” yang digunakan di desa Tanjung Mompang yaitu "dogu, moti, cinto, sirop, lori” dan dalam bahasa Mandailing "isang, mate, cinta, siram, lojong". Vokal "a" lebih banyak dibuat atau diganti menjadi vocal "o". namun, ada juga perbedaan yang sangat berbeda jauh penggunaan bahasa dalam bahasa Indonesia dan bahasa yang digunakan di Desa Mompang Jae atau pun bahasa Mandailing yaitu terletak pada kata "celana, celaka, lapar, lelah, pegang, jalan" dalam bahasa Indonesia, dan dalam bahasa yang digunakan di Desa Tanjung Mompang yaitu "sorewa, bo moru, koloparet, jerih, pagak dan jalet". Walau begitu, masyarakat di Desa Tanjung Mompang tetap mengerti bahasa Indonesia dan bahasa Mandailing.

\section{Kata Afiksasi}

Dari hasil analisis dan wawancara yang dilakukan, ternyata kata afiksasi Bahasa Mandailing dengan bahasa yang digunakan di Desa Tanjung Mompang terdapat perbedaan yang paling kontras yaitu terletak pada afiksasi "...-nya" dalam bahasa Indonesia menjadi “...-nyo” pada bahasa yang digunakan di Desa 
Tanjung Mompang, sedangkan dalam bahasa Mandailing menjadi “...-na”. namun ada juga afiksasi yang sama dalam bahasa Indonesia dengan yang digunakan dalam bahasa di desa Tanjung Mompang yaitu afiksasi ataupun awalan "di" yang dalam bahasa Mandailing menjadi awalan "i”", selanjutnya awalan "me- dalam bahasa Indonesia bisa berubah menjadi awalan "mo-" dalam bahasa yang digunakan di Desa Tanjung Mompang. Awalan "per-" menjadi awalan "por-" dalama bahasa yang digunakan di desa Tanjung Mompang, sedangkan dalam bahasa Mandailing menjadi awalan "par-", Awalan "me-" dalam bahasa Indonesia menjadi awalan "mo-" dalam bahasa yang digunakan di desa Tanjung Mompang, sedangkan dalam bahasa Mandailing menjadi awalan "ma-"

\section{Kata Reduplikasi}

Dari hasil analisis dan wawancara yang dilakukan, ternyata kata reduplikasi Bahasa Mandailing yang digunakan di Desa Tanjung Mompang dengan bahasa Indonesia hampir sama dengan kata dasar, sama-sama memiliki perbedaan kontras yang terletak pada vokal 'o' dan kebanyakan semua kata ulang utuh. contoh kata seperti "bolori-lori, komori-komori, bologu-logu, monori-nori" yang dalam bahasa Mandailing adalah "marlojong-lojong, tuson-tuson, marlagulagu,manari-nari" dan dalam Bahasa Indonesia "berlari-lari, kemari-kemari, bernyanyi-nyanyi, menari-nari”. Dalam reduplikasi bahasa yang digunakan di desa Tanjung Mompang ternyata awalan "se-..." menjadi awalan "so-..” dalam bahasa yang digunakan di desa Tanjung Mompang dan dalam Bahasa Mandailing menjadi awalan "sa-..." terletak pada kata "sobaik-baiknyo, sobanyak-banyaknyo, so pintar-pintarnyo" yang dalam bahasa Mandailing "sadenggan-dengganna, sabahat-bahatna, sapintar-pintarna" dan dalam bahasa Indonesia menjadi "sebaikbaiknya, sebanyak-banyaknya, sepintar-pintarnya". Selain itu ada juga reduplikasi yang sama dalam bahasa yang digunakan di desa Tanjung Mompang dengan bahasa Mandailing dan dalam bahasa Indonesia yaitu kata "gerak-gerik" mungkin padanannya terlalu sulit dicari sehingga masyarakat yang ada di desa Tanjung Mompang masih menggunakan bahasa yang sama. Selain itu ada juga kata reduplikasi yang perubahan katanya sangat berbeda contoh pada kata "kebake- 
bake, torum-bakambik" yang dalam bahasa MAndailing berarti "hobar-hobari, tarombang-ambing" dan dalam bahasa Indonesia berarti "kabar-kabari, terombang-ambing"

\section{KESIMPULAN}

Berdasarkan hasil analisis dan wawancara dapat disimpulkan bahwa perbedaan kontrastif kata dasar, afiksasi dan reduplikasi di desa Tanjung Mompang lebih dominan menggunakan vokal 'o'. Masyarakat yang ada di desa Tanjung Mompang tetap paham tentang bahasa Mandailing, walau desa Tanjung Mompang terletak di tengah-tengah Kabupaten Mandailing Natal dan berada di Kecamatan Panyabungan Utara ternyata bahasa yang mereka gunakan lebih mirip dengan bahasa yang ada di Desa Muarasipongi atau desa yang terletak di perbatasan antara Mandailing Natal dengan Sumatera Barat.

\section{DAFTAR PUSTAKA}

Alwi, Hasan dkk. 2003. Tata Bahasa Baku Bahasa Indonesia. Jakarta: Balai Pustaka.

Chaer dan Agustina. 2010. Sosiolinguistik Perkenalan Awal. Jakarta. PT Rineka Cipta

Chaer, Abdul \& gustina. Leonie. 2004. Sosiolinguistik Perkenalan awal. Jakarta:Rineka Cipta

Finoza, Lamuddin. 2009. Komposisi Bahasa Indonesia untuk Mahasiswa Nonjurusan Bahasa. Jakarta: Mawar Gempita.

Gulo, W. 2007. Metodologi Penelitian. Jakarta:PT Gramedia Widiasarana Indonesia

Harahap, Basyral Hamidy. 2004. Madina yang Madani. Jakarta Timur: Metro Pos.

Kosasih, Eko. 2011. Ketatabahasaan dan Kesusastraan Cermat Berbahasa Indonesia. Bandung: CV.Yrama Widya

Kridalaksana, Harimurti. 1984. Pembentukan Kata dalam Bahasa Indonesia. Jakarta: Gramedia

Maeliono, M. Anton. 1988. Tata Bahasa Baku Bahasa Indonesia. Jakarta: Balai Pustaka

Ramlan. 2001. Ilmu Bahasa Indonesia:Sintaksis. Yogyakarta.: Up Karyono

Sugiono. 2010. Metode Penelitian Kuantitatif Kualitatif dan R\&D. Bandung: Alfabeta

Suwito. 1985. Pengantar Awal Sosiolinguistik. Surakarta: Henary Offset 